\title{
Typical Hydraulic Properties of Deep Aquifers of Niger Delta from Pumping Test Data
}

\author{
S. A. Ngah, C. L. Eze \\ Institute of Geosciences and Space Technology, Rivers State University, Port Harcourt, Nigeria \\ Email:ngahsab@yahoo.com
}

How to cite this paper: Ngah, S.A. and Eze, C.L. (2017) Typical Hydraulic Properties of Deep Aquifers of Niger Delta from Pumping Test Data. Journal of Geoscience and Environment Protection, 5, 139-148. https://doi.org/10.4236/gep.2017.511010

Received: September 28, 2017

Accepted: November 13, 2017

Published: November 16, 2017

Copyright ( 92017 by authors and Scientific Research Publishing Inc. This work is licensed under the Creative Commons Attribution International License (CC BY 4.0).

http://creativecommons.org/licenses/by/4.0/ (c) (i) Open Access

\begin{abstract}
The hydraulic properties of deeper Coastal Plain Sands, which form the main aquifer in the Niger Delta, were investigated around Eleme, Rivers State. The intent was to find out if frequent well failure was as a result of the aquifer not having enough transmitting capacity to sustain the huge withdrawal necessary for Eleme and its environs where demand for groundwater withdrawal is very high because Eleme axis serves as a major industrial axis of River State or whether the frequent well failure was due to inefficient well construction practice. Constant discharge pumping tests were conducted in 8 deep borehole $(250-310 \mathrm{~m})$. Data generated during the test were analysed using Cooper-Jacob's straight line method. The calculated transmissivity of the aquifers ranged from $1324 \mathrm{~m}^{2} /$ day $-5815 \mathrm{~m}^{2} /$ day. These values when compared with transmissivity values elsewhere indicate that the aquifers in the study area have excellent water yielding properties, plotting within the range of "Very Good" in water transmitting capacity scale. Coefficient of permeability ranged from $13.65 \mathrm{~m} / \mathrm{d}-59.9 \mathrm{~m} / \mathrm{d}$. Coefficient of Storage ranged from $28.2 \times 10^{-5}$ $29.1 \times 10^{-5}$ while the Specific capacities of the wells ranged from $48.753-$ $78.13 \mathrm{~m}^{3} / \mathrm{d} / \mathrm{m}$. It is concluded that the deep aquifers of the Niger Delta do possess the capacity to produce and sustain large groundwater withdrawal. It is further recommended that competent drilling contractors be engaged in deep well construction in the area.
\end{abstract}

\section{Keywords}

Deep Aquifers. Hydraulic Properties, Coastal Plain Sands, Eleme, Niger Delta

\section{Introduction}

Water as a finite resource is becoming very scarce in most nations of the world.

The competition for the available supplies among users such as the residential, 
agriculture, and industries will continue to put great stress on water supply especially in arid and semi-arid areas where water shortage could constitute an important constraining economic factor. Besides, high rate of urbanization and rapidly increasing population are also known to have contributed to water stress even in non-arid areas.

This ever increasing demand for water is more pronounced in areas with high concentration of industries like Eleme, Rivers State, a semi-urban community and plays host to such companies as Eleme Refinery, Eleme Petrochemicals Company, Onne Oil and Gas Free Zone, Federal Light Terminal, Onne, Nigerian Ports Authority, Naval College etc. The existence of these companies and ancillary outfits has resulted in very large influx of people who now live and work at Eleme. Water supply projections became grossly inadequate. Surface water sources are either saline or polluted by long history of oil and gas activities. Groundwater becomes the viable option for domestic and industrial water supplies. Residents therefore resort to indiscriminate sinking of shallow water boreholes and hand dug wells for their domestic water needs. These boreholes were completed into the Coastal Plain Sands which is the surface outcrop of the Benin Formation often covered by superficial Alluvial deposits.

In response to the increased water demand, a series of water supply projects based on groundwater had been embarked upon by both public and private sectors. These interventions were largely unplanned, uncoordinated and guided by no hydrogeological studies whatsoever. The drilling itself was done by people who have no skills or training relevant to it and as a result, no hydrogeological records were kept, and no analysis was carried out. Most of the boreholes therefore became abortive and huge sums of money spent on their construction went down the drains. The bigger companies that can afford the budget, now have their boreholes drilled into deeper aquifers for fear of imminent regional groundwater level decline which might adversely affect their production. The costs of such deep wells are usually very high.

Previous studies on this subject concentrated on the hydraulic characteristics of first aquifer as the technology for deep well drilling was not very affordable then [1] [2] [3]. In this work, the water-yielding properties of deep aquifers which are the target of the deep wells are evaluated not only to fill the knowledge gap but also to reduce the financial loss involved in constructing abortive deep boreholes that result from lack of knowledge of water yielding potentials of the aquifers at various depths. It will also enhance the success rate in borehole drilling if more competent drilling contractors are engaged hence result in improved water supply in this economically strategic area of the country.

\section{Geology and Geomorphology of the Study Area}

The geology of the area is typical of the geology of the Niger Delta. The Niger Delta itself (Figure 1) and has been described by previous workers [4] [5] [6] [7] as well as records of exploration activities of the oil and gas companies in Nigeria. 


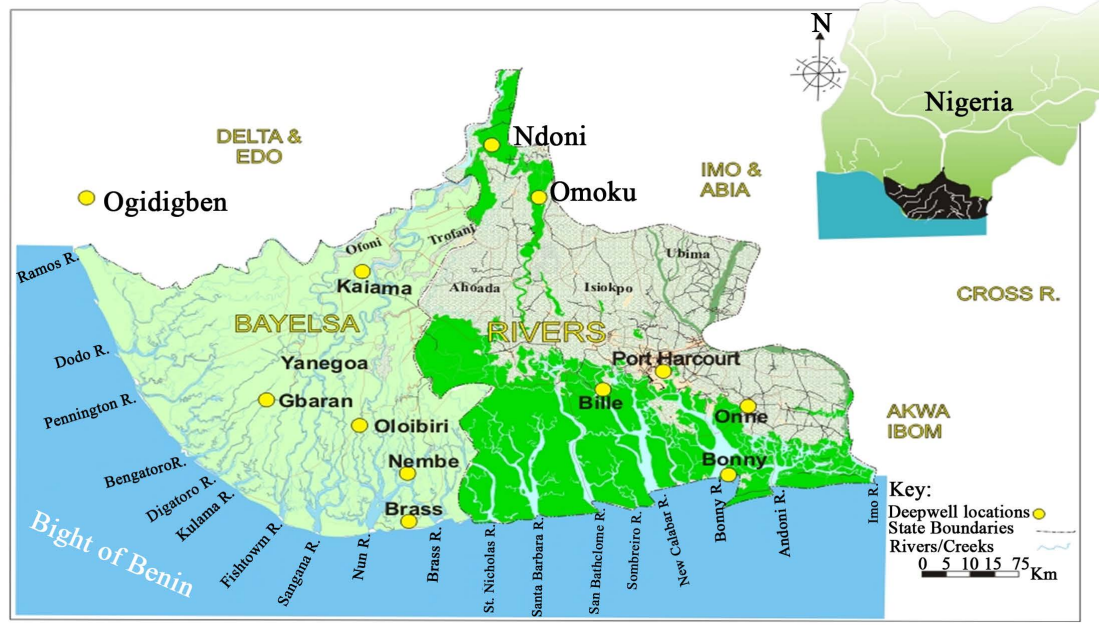

Figure 1. Location map of the study area.

However, the modern Niger Delta was formed during the third and last depositional cycle of the southern Nigerian basin which started in the Paleocene. The Niger Delta sedimentary sequence had been divided into the oldest Akata Formation (Paleocene), Agbada Formation (Eocene) and the Youngest Benin Formation (Miocene to Recent) [5].

The major aquiferous formation is the Benin Formation which is about 2100 $\mathrm{m}$ thick at the centre of the basin and consists of coarse-medium grained sandstones, thick shales and gravels. The upper section of the Benin Formation is the quaternary deposits which is about $40-150 \mathrm{~m}$ thick and comprises sand and silt/clay with the later becoming increasingly more prominent seawards [3]. The formation consists of predominantly freshwater continental friable sands and gravel that have excellent water-yielding properties with occasional intercalations of claystone/shales The Benin Formation is highly permeable and prolific and is the target of most water boreholes in the Niger Delta. Five [5] major geomorphologic units have been identified in the Niger Delta [8]: the coastal plain sands (dry flatland and plain), the Sombreiro-Warri Deltaic plain (with abundant freshwater swamps), the freshwater swamps (backswamps, alluvial plain and meander belts), the saltwater or mangrove swamps and the active/abandoned coastal beaches (sand bars, beaches and bars).

Water table is shallow in most parts of the area, fluctuating between near surface and $18 \mathrm{~m}$. Influent conditions may occur in some places in the dry season between water levels in the rivers and the shallow aquifers. The groundwater level usually drops below the river water level, creating a head differential which induces flow of river waters into the aquifers. The rivers, therefore, partly recharge the upper aquifers and may pollute them with dissolved toxic or hazardous materials [9]. The quaternary deposits obtain steady recharge by direct precipitation. The main body of groundwater in the Niger Delta is contained in the very thick and extensive sand and gravel aquifers. Three main zones have been differentiated. These are: a northern bordering zone consisting of shallow aquifers 
of predominantly continental materials and a coastal zone of intermixing marine and continental deposits [1] [3] [10]. The aquifers in the study area are more continental in character, being composed of river loads coming from the hinter lands. They are encountered at very shallow depths that shallow boreholes can be completed even at less than $20 \mathrm{~m}$ using manual drilling methods.

Rainfall is high in the area (mean, $300 \mathrm{~mm} / \mathrm{yr}$ ). Evapotranspiration and Relative Humidity are high and remain high all the year round. This is due, mainly, to the coastal nature of the area. Figure 2 shows typical response of groundwater level to monthly rainfall distribution for Eleme-Okochiri area behind the Port Harcourt Refinery Company.

Moderately high temperature $\left(24^{\circ} \mathrm{C}-34.5^{\circ} \mathrm{C}\right)$ and long periods of sunshine prevail in the dry season. Human beings perspire profusely under the intense heat of the sun necessitating frequent desire for water to remain hydrated. The relief is generally low with average elevation between $20 \mathrm{~m}$ and $30 \mathrm{~m}$ above sea level [11] (2015) and gently sloping seaward. The vegetation in the area includes raffia palms, secondary regrowth complexes and thick rain forest. The soil is usually sandy or sandy loam underlain by a layer impervious pan and is always leached due to the heavy rainfall. Overland flow is high due to continuous heavy rainfall and built-up nature of the area resulting in severe annual flooding.

\section{Materials and Method}

\section{1) Instrumentation}

The following instruments were used in carrying out the pumping test: a 75HP Grundfos submersible pump equipped with starter panel, cable, and risers. The pump was installed and pulled out using a Gardner Denver 1500 HD drilling rig. Power supply for the test was provided by a $150 \mathrm{KVA}$ Perkins generator. The yield was read out on a calibrated flow meter installed on the flow line equipped with both butterfly and non-return valves. Water level changes during

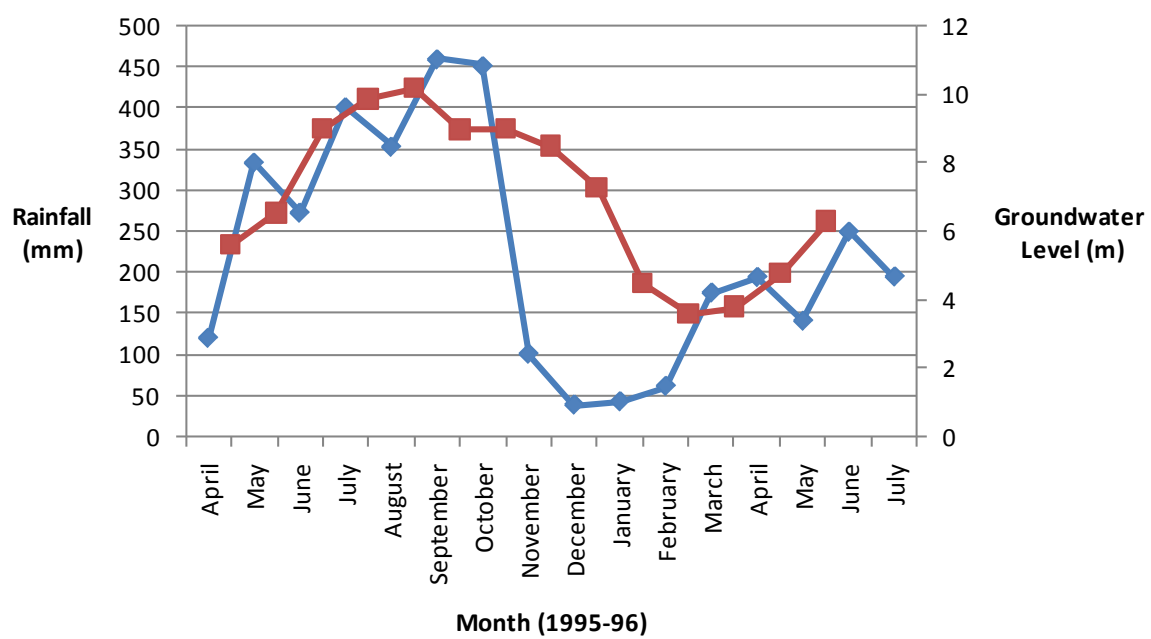

Figure 2. Typical response of groundwater level to monthly rainfall distribution in Eleme-Okochiri, Rivers State. 
pumping and recovery were measured using an electronic dip meter while time was measured using stopwatch. All readings were recorded in a field note book and later analysed using the computer.

\section{2) Principles of Pumping Tests}

The principle of pumping tests is fairly simple. When a submersible pump installed in a borehole is energized, a significant elevation difference is created between the water level in the well and the water level in the aquifer surrounding the borehole. This difference in head forces the water in the aquifer to flow towards the well. The pumping causes a dewatering of the aquifer (unconfined aquifer) or reduction of confining pressure (confined aquifer) and hence creates a cone of depression on the water table. The dewatering of aquifer or reduction in confining pressure both result in the flow of water out of the well leading generally to water level decline in the pumped well and nearby observation well. Measuring this water level decline at specific time intervals is what aquifer tests seek to achieve. The measured values of piezometric head or water table decline are compared with mathematical solutions and the transmissivity, T; hydraulic conductivity, K; the coefficient of storage, $\mathrm{S}$; and the specific capacity of the well can be calculated. Armed with knowledge of the above parameters, groundwater withdrawal can be effectively planned such that no undesirable consequences are induced.

Pumping tests are expensive to conduct and as such are not commonly included in most borehole drilling contracts in the Niger Delta. A generalized cost of pumping test can be determined by the following relationship modified after [12].

$$
\text { Cost of pumping test }(\text { USD })=136 \times \text { hours }^{0.66} \times 300
$$

The model emphasized the relationship between cost and duration of pumping.

\section{3) Data collation and Analysis}

The results of the pumping tests carried out in eight deep boreholes at Eleme Petrochemicals Complex are analysed based on Jacob's (1964) straight line, semi log method, [13] (a modification of Theis (1935) equation), [14] which expresses transmissivity, $T$, as

$$
T=\frac{0.183 Q}{\Delta s}
$$

where $\Delta s=$ drawdown per log cycle of time = slope of time vs drawdown plot on semi-log table, $T=$ transmissivity of the aquifer $\mathrm{m}^{2} / \mathrm{d}$ and $Q=$ discharge of the well $\left(\mathrm{m}^{3} / \mathrm{d}\right)$.

Each data set was plotted with the drawdown $(m)$ values regressed on time (minutes since pumping started), using MICROSOFT EXCEL. The slope of the time vs drawdown graph gives a value for $\Delta s$, in Jacob's equation. With a known discharge rate, $Q, T$ can be calculated simply by substituting into the equation. The slope of the straight line is $\Delta s$, the drawdown per log cycle of time and can be obtained as a vertical projection of the straight line between two numbers on 
the time axis that are logarithm one unit apart. Water level decline is usually very rapid as soon as the pump is started due to rapid depletion of "well bore" or casing storage [15] [16]. Therefore early pumping test data will not fit into Jacob's modification of the non-equilibrium formula as the $\Delta s$ will be higher during the time required to exhaust the casing storage giving erroneously low $T$ value in the early stages of the test. To compensate for this, a regressed line of best fit is generated and the slope used to calculate the representative $T$ value.

Using the resulting regression equation,

$$
\begin{aligned}
& y_{1}=m(\ln x)+C \\
& y_{2}=m(\ln x)+C
\end{aligned}
$$

By definition, the slope per log cycle of time means

$$
y_{2}-y_{1}=\Delta s
$$

The slope of the drawdown vs time plot was calculated for each of the wells using the above procedure. The values for each well pumped-tested was substituted into relevant equation and the relevant hydraulic parameters calculated.

With $\Delta s$ known, the hydraulic parameters of the aquifer were calculated as follows:

\section{a) Transmissivity}

$T$, a measure of the ease with which an aquifer allows water to pass through its pore spaces in response to pumping or drainage forces was calculated using the equation

$$
T=\frac{0.183 Q}{\Delta s}
$$

\section{b) Coefficient of permeability/hydraulic conductivity, $k$}

This is the constant of proportionality in Darcy's law. It is the property of a water bearing formation that relates to its conduit function. When the saturated thickness of the aquifer is known, $k$ can be calculated from the relation

$$
T=K b
$$

where, $K=$ hydraulic conductivity ( $\mathrm{m} /$ day), $b=$ the saturated thickness of the aquifer $(\mathrm{m})$ and $T=$ transmissivity $\left(\mathrm{m}^{2} /\right.$ day $)$

\section{c) Coefficient of storage, $S$}

Since the coefficient of storage varies directly with aquifer thickness, $b$, it can be estimated from known values of $b$, using the following relationship, Todd (1980)

$$
S=3 \times 10^{-6} b
$$

\section{d) Specific capacity}

The specific capacity of a well is its yield per unit drawdown, usually expressed in $\mathrm{m}^{3} / \mathrm{hr} / \mathrm{m}$ of drawdown. It decreases in direct proportion with drawdown. Its maximum corresponds to zero drawdown while the minimum occurs when the drawdown and yield are at the maximum.

$$
\text { Specific capacity }=Q / s
$$




\section{Results and Discussions}

Figures 3-6 are representative time-drawdown graphs for borehole 2, 3, 5, 6 and 7 respectively. The hydraulic parameters calculated for each of the wells are shown in Table 1. The table also shows the total depth of the boreholes. These values are in general agreement with earlier estimates of hydraulic parameters for shallower boreholes in the Niger Delta [17] [18].

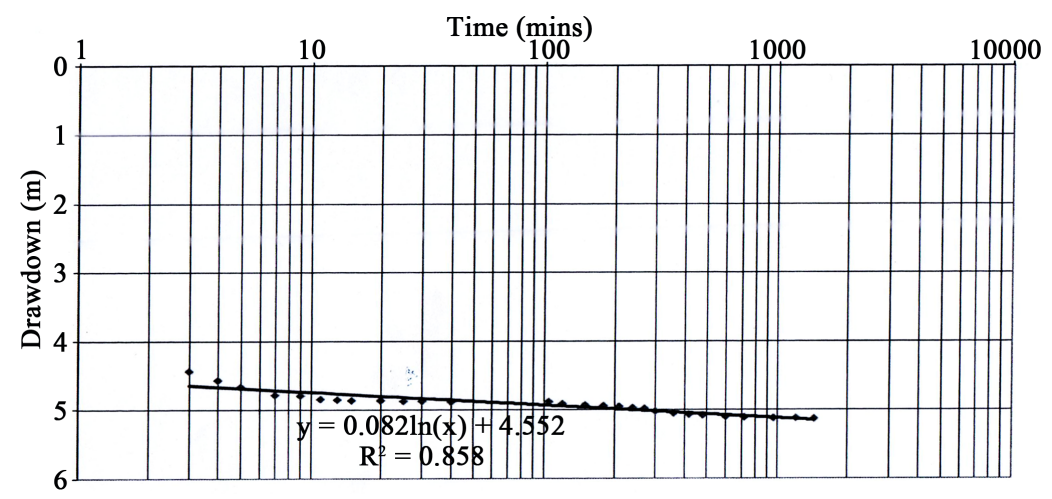

Figure 3. Time vs drawdown plot for eleme petrochemicals BH No. 2.

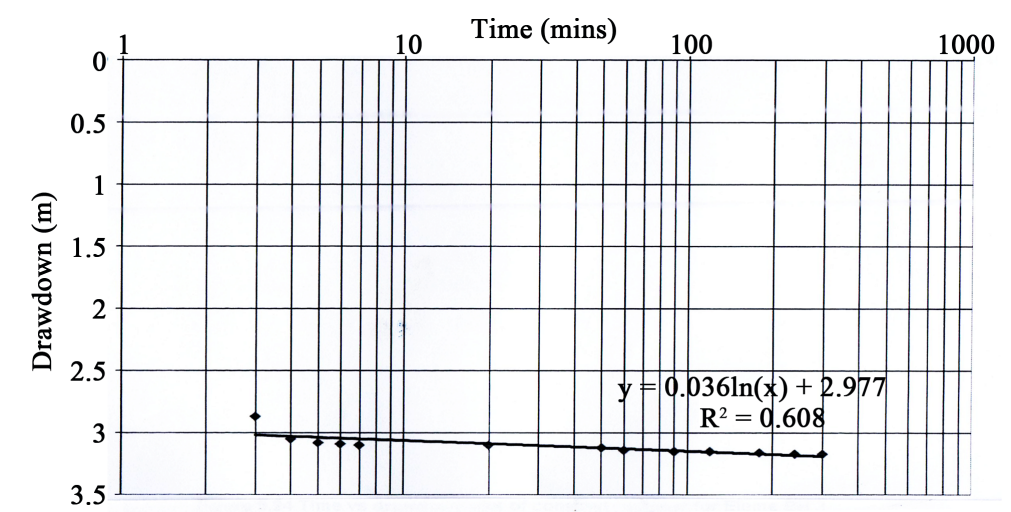

Figure 4. Time vs drawdown plot of constant rate test for eleme BH 3.

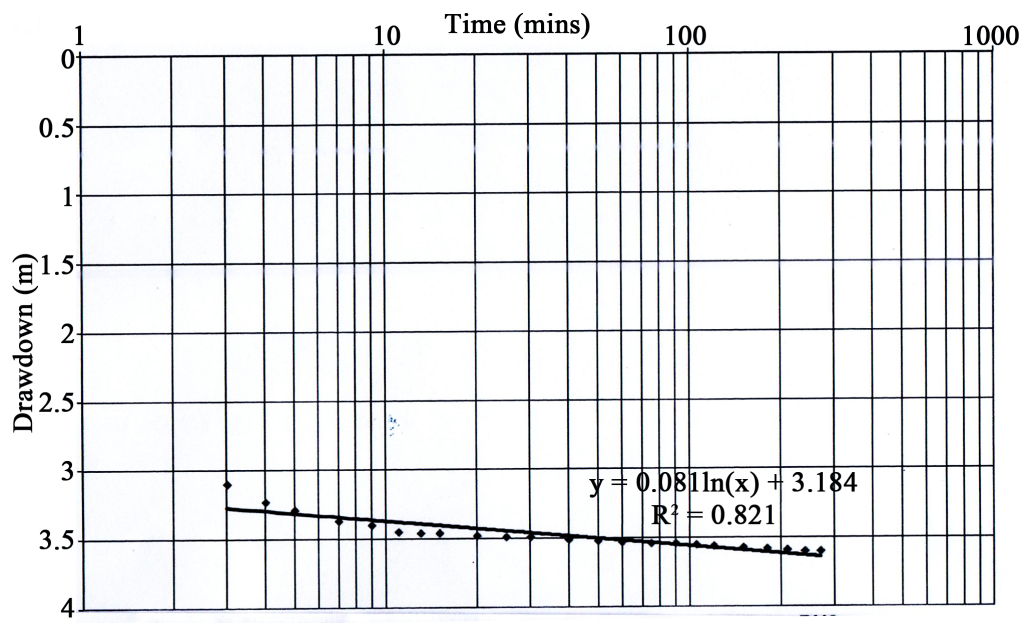

Figure 5. Time vs drawdown plot of constant discharge rate for eleme BH 6 . 


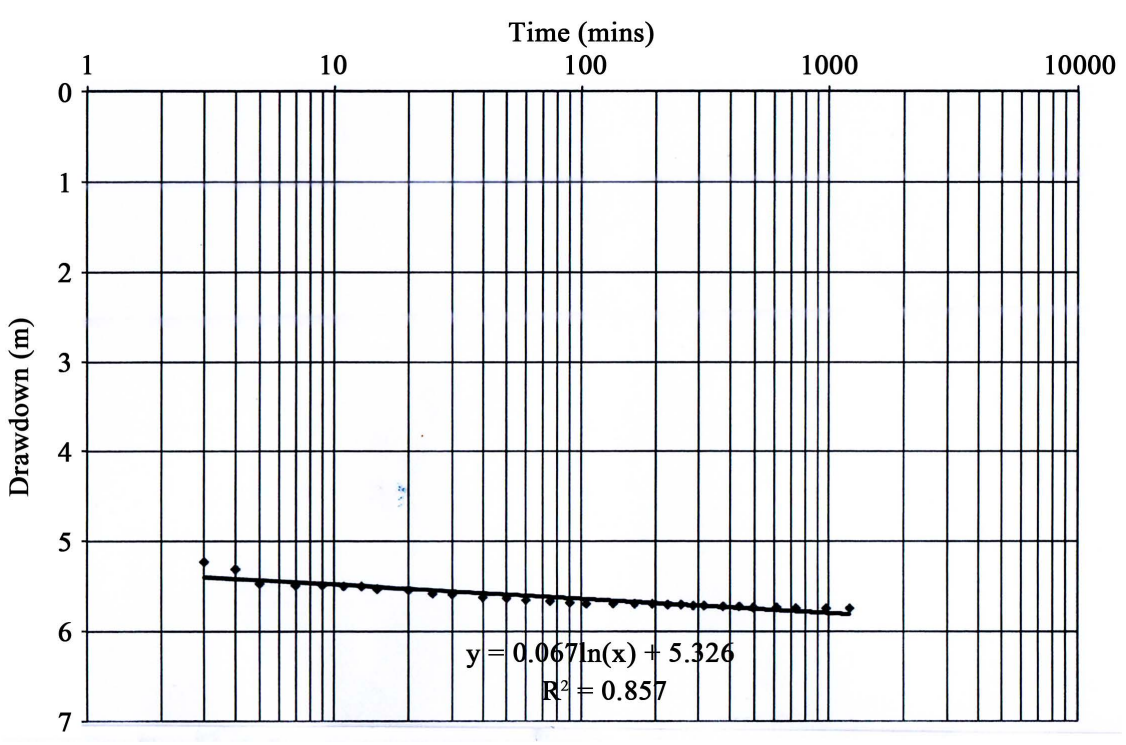

Figure 6. Time vs drawdown plot of constant discharge rate test for eleme $\mathrm{BH} 7$.

Table 1. Values of hydraulic parameters calculated for the aquifers in the study area.

\begin{tabular}{|c|c|c|c|c|c|c|c|c|}
\hline \multirow{2}{*}{ S/No } & \multirow{2}{*}{ Location } & \multirow{2}{*}{$\mathrm{BH} \#$} & \multirow{2}{*}{ Depth } & \multicolumn{2}{|c|}{ Transmissivity, $T$} & \multirow{2}{*}{$\begin{array}{c}k \\
(\mathrm{~m} / \mathrm{day})\end{array}$} & \multirow{2}{*}{$S$} & \multirow{2}{*}{$\begin{array}{l}\text { Specific } \\
\text { Capacity } \\
\mathrm{m}^{3} / \mathrm{hr} / \mathrm{m}\end{array}$} \\
\hline & & & & $\mathrm{m}^{2} /$ day & $\mathrm{m}^{2} / \mathrm{sec}$ & & & \\
\hline 1 & $\begin{array}{c}\text { Eleme } \\
\text { Petrochemical }\end{array}$ & 2 & 310 & 3772.8 & $43.6 \times 10^{-3}$ & 38.9 & $29.1 \times 10^{-5}$ & 48.73 \\
\hline 2 & $\begin{array}{c}\text { Eleme } \\
\text { Petrochemical }\end{array}$ & 3 & 310 & 4500 & $52 \times 10^{-3}$ & 46.4 & $29.1 \times 10^{-5}$ & 78.13 \\
\hline 3 & $\begin{array}{c}\text { Eleme } \\
\text { Petrochemical }\end{array}$ & 5 & 226 & 5676 & $65.6 \times 10^{-3}$ & 60.38 & $28.2 \times 10^{-5}$ & 52.08 \\
\hline 4 & $\begin{array}{c}\text { Eleme } \\
\text { Petrochemical }\end{array}$ & 6 & 310 & 6357.6 & $73.5 \times 10^{-3}$ & 65.54 & $29.1 \times 10^{-5}$ & 69.25 \\
\hline 5 & $\begin{array}{l}\text { Eleme } \\
\text { Petrochemical }\end{array}$ & 7 & 230 & 5961.6 & $69 \times 10^{-3}$ & 63.42 & $28.2 \times 10^{-5}$ & 43.55 \\
\hline 6 & $\begin{array}{c}\text { Eleme } \\
\text { Petrochemical }\end{array}$ & 8 & 230 & 3096 & $35.8 \times 10^{-3}$ & 32.94 & $28.2 \times 10^{-5}$ & 48.92 \\
\hline
\end{tabular}

The calculated values of $\mathrm{T}$ in this study were also compared with Kampsax-Kruger (1985) classification for aquifers in the Niger Delta [19] shown in Table 2.

From the table above, the aquifers underlying Eleme Petrochemical Complex have "Very Good" water transmitting capability. The calculated transmissivity values were also compared with Krasny (1993) classification [20] (Table 3).

Based on this classification, the transmisivity of the aquifers falls within "very high" (II) implying that the aquifers can sustain regional and great regional withdrawls. Therefore, the deep aquifers underlying Eleme Petrochemicals complex can sustain withdrawal of great regional importance. 
Table 2. Kampsax-Kruger's rating of T values [19].

\begin{tabular}{cc}
\hline Transmissivity Range $\left(\mathrm{m}^{2} / \mathrm{sec}\right)$ & Water \\
\hline$T<1 \times 10^{-3}$ & Poor \\
$1 \times 10^{-3}<T<5 \times 10^{-3}$ & Medium \\
$5 \times 10^{-3}<T<1 \times 10^{-3}$ & Good \\
$1 \times 10^{-2}<T$ & Very Good \\
\hline
\end{tabular}

Table 3. Krasny classification of transmissivity [20].

\begin{tabular}{cccc}
\hline $\begin{array}{c}\text { Coefficient of } \\
\text { Transmissivity } \\
\left(\mathbf{m}^{2} / \text { day }\right)\end{array}$ & $\begin{array}{c}\text { Class of } \\
\text { Transmissivity } \\
\text { magnitude }\end{array}$ & $\begin{array}{c}\text { Designation of } \\
\text { Transmissivity } \\
\text { magnitude }\end{array}$ & $\begin{array}{c}\text { Groundwater supply } \\
\text { Potential }\end{array}$ \\
\hline I & Very high & $\begin{array}{c}\text { Withdrawals of great } \\
\text { regional importance. }\end{array}$ \\
1000 & II & High & $\begin{array}{c}\text { Withdrawals of lesser } \\
\text { regional importance. }\end{array}$ \\
100 & III & Intermediate & Withdrawals for local water \\
10 & IV & Low & Suply (small communities, Plants, etc.) \\
1 & V & Very Low & Supply (private consumption) \\
& & & Withdrawals for local water \\
0.1 & VI & Imperceptible & $\begin{array}{c}\text { Sources for local water Supply are } \\
\text { difficult (if possible) to ensure. }\end{array}$ \\
\hline
\end{tabular}

\section{Conclusion}

Pumping test results show that the Coastal Plain sands have excellent water yielding properties even at great depths. The problem of frequent borehole failure and large records of abortive boreholes in the area cannot be blamed on the inability of the aquifer to yield enough water. This observation clearly puts the blame on the competence of the drilling contractors. To improve on the success rate particularly in deep boreholes, efforts should be made to engage suitably qualified and equipped water well drilling contractors for borehole drilling, installation and development projects.

\section{References}

[1] Etu-Effeotor, J.O. and Odigi, M.I. (1983) Water Supply Problems in the Eastern Niger, Delta. Jl. Nigerian Min. Geosci. Assoc., 20, 183-192.

[2] Amajor, L.C. (1991) Aquifers in the Benin Formation (Miocene-Recent) Eastern Niger Delta, Nigeria: Lithostraigraphy, Hydraulics and Water Quality. Environmental Geology and Water Sciences, 17, 85-101. https://doi.org/10.1007/BF01701565

[3] Etu-Efeotor, J.O. and Akpokodje, E.G. (1990) Aquifer Systems of the Niger Delta. Nig. J. Min. Geol., 26, 279-285.

[4] Reyment, R.A. (1965) Aspects of the Geology of Nigeria. Ibadan Univ. Press, Ibadan 
$145 \mathrm{p}$.

[5] Short, K.C. and Stauble, A.J. (1967) Outline of the Geology of the Niger Delta. Bulletin of $A A P G, 51,761-779$.

[6] Murat, R.C. (1972) Stratigraphy and Paleogeography of the Cretaceous and Lower Tertiary in Southern Nigeria. In: Dessauvagie, T.F.J. and Whiteman, A.J., Eds., African Geology, Univ. Ibadan, Ibadan, 251-266.

[7] Oomkens, E. (1974) Lithofacies Relations in the Late Quateernary Niger Delta Complex. Sedimentology, 21, 195-222. https://doi.org/10.1111/j.1365-3091.1974.tb02056.x

[8] Akpokodje, E.G. (1987) The Engineering Geological Characteristics and Classification of the Major Superficial Soils of the Niger Delta. Engineering Geology, 23, 193-211. https://doi.org/10.1016/0013-7952(87)90090-1

[9] Ngah, S.A. (1990) Groundwater Resource Development in the Niger Delta: Problems and Prospects. Proceedings of 8 th International IAEG Congress, Balkema, Rotterdam, 1379-1386.

[10] Wokocha, C.C and Omenihu, E.R. (2015) Land Resources Appraisal and Management Activities using Remote Sensing Techniques: Case Study of Akpor Town, Rivers State. Research Journal of Environment and Earth Science, 5, 145-152.

[11] Anon, G.E. (1977) Groundwater Manual: A Water Resources Technical Publication. U.S. Dept of the Interior Bureau for Reclamation, Washington DC, 97 p.

[12] Cooper Jr., H.H. and Jacob, C.E. (1964) A Generalized Graphical Method for Evaluating Formation Constants and Summarizing Well Field History. Transactions on American Geophysical Union, 27, No. 4.

[13] Theis, C.V. (1935) The Relation between the Lowering of the Piezometic Surface and the Rate and Duration of Discharge of a Well Using Groundwater Storage. Transactions on American Geophysical Union, Washington DC, 518-524.

[14] Schafer, D.C. (1978) Casing Storage Can Affect Pumping Test Data. Johnson Driller's Journal, Jan/Feb. Johnson Div. UOP Inc, St. Pauls, MN.

[15] Kruseman, G.P. and de Ridder, J.M. (1990) Analysis and Evaluation of Pumping Test Data. ILRI Publication 47, 377 p.

[16] Todd, D.K. (1980) Groundwater Hydrology. John Willey and Sons Inc, New York, $336 \mathrm{p}$.

[17] Allen, R.O. (1992) Iron and Chloride Groundwater Contaminants in Rivers State: Geographic and Stratigraphic Distribution and Genesis. Unpublished M.Sc Thesis. University of Port Harcourt, $137 \mathrm{p}$.

[18] Etu-Efeotor, J.O. (2000) Hydraulic Characteristics of the Aquifers within the Oligocene-Recent Coastal Plain Sands Parts of Southern Nigeria. Global Jl Pure and Applied Sciences, 6, 107-115.

[19] Kampsax-Kruger (1985) Final Report on Hydrogeological Site Studies for Water Well Development NAFCON Phase I. Study Report Submitted to Federal Ministry of Commerce and Industry, Abuja, $118 \mathrm{p}$.

[20] Krasny, J. (1993) Classification of Transmissivity Magnitude and Variation. Groundwater, 31, 230-236. https://doi.org/10.1111/j.1745-6584.1993.tb01815.x 